\title{
THE EFFECTIVENESS OF SPATIAL ORDER IN WRITING A DESCRIPTIVE TEXT
}

\author{
Endru Dwi Yuninan, Zakiya Isnani \\ gamazhamaz@gmail.com, zakiya86isnani@gmail.com \\ Program Studi Pendidikan Bahasa Inggris Universitas Islam Lamongan, Program Studi Manajemen \\ Informatika Sekolah Tinggi Teknologi Gempol Walisongo
}

\begin{abstract}
Students sometimes face some difficulties to make a writing. They have difficulties to change the sentence into a good paragraph and how to combine it as a good text structure. This research used a spatial order technique in writing a descriptive text. Spatial Order is a technique of writing based on the space in the order. The purpose of the research is to know the effectiveness of the spatial order technique in writing a descriptive text, and how is the student's response towards it. The research is conducted in MA Sains Roudlotul Qur'an. The research used pre-experimental research with one group pre-test and post-test design. The sample is X MIPA 2 class with using purposive sampling technique to choose the sample. The data from the test is analyzed using t-test checking to find the significance of the data. On the other hand, the data from the questionnaire is analyzed with finding the percentage of the data. The result of the research shows that the number of t-tests which is to find the effectiveness of the technique is 6,65. It is higher than t-table score at significance 0,1 that is ( $\mathrm{t}$-test $=6,65>\mathrm{t}$-table $=1,69$ ). By means, Ha that it is Effective to use spatial order in writing a descriptive text is accepted. On the other hand, the respond of the students showed that $78 \%$ of the students give positive feedback in using this technique. By means, the students give a positive response to this technique.
\end{abstract}

Keywords: Spatial Order, descriptive text

\section{INTRODUCTION}

English language skill contains four skills, they are very important for language learners. They are listening, speaking, reading, and writing. Those skills will help in how to use the language in a good way, especially for communication. In this study, the researcher taken one of them. It is writing skill. Writing is a process of rearranging the capability in a language into several words that tell about something. There are several kinds of writing. The first is academic writing. Oshima \& Hogue (2007:3) said that academic writing is the kind of writing that used for academic purposes. Academic purpose means for education, college, or classes. Second, there is personal writing. Oshima \& Hogue (2007:3) said personal writing is a kind of text that used for personal purposes. It is to write a letter or e-mail to the personal subject with personal information. Last, there is creative writing. Oshima \& Hogue
(2007:3) said that creative writing is the kind of writing that used to express creativity with the purpose to attract the reader. It can become a short story, novel, or poem. All those kind of writing has its characteristics.

Writing also divides into formal and informal writing. Formal writing is a kind of writing that used for formal situations. That is for a job or academic purpose. In writing a formal text, it should be constructed formally. There is no longer to use contraction or slang in a formal language (Oshima \& Hogue 2007:3). That is because it is impolite to use slang or contraction in a formal situation. The next is informal writing. Informal writing is a kind of text used for the informal situation. That is for personal, entertainment, or creativity purpose. In this writing, it is allowed to used slang or contraction in using this kind of writing to express all of the thoughts using all of the knowledge include slang into this kind of writing. By 
deciding the kind of writing, can help to make writing for the right purpose with the right structure and contents of the writing based $n$ the situation or the reader of the text.

Sometimes, the students find it difficult to make good writing. They still do not have an idea about how to make those kinds of writing. They have some problem to choose the right diction in formal writing, it is supposed to be using a formal language. They also do not have a rich vocabulary to make an attractive creative writing, it is supposed to be entertaining for the reader. Furthermore, they also face some problem to classify the vocabulary that is applied in formal or informal writing.

To make good writing, it needs to follow some steps. It is called the writing process, they are: 1) Pre-Writing. It is the preparation of writing. That is the step that is taken before do writing. Pre-Writing is a step that helps to collect some ideas (Oshima \& Hogue, 2007:16). It consists of choosing the topic, brainstorming, and gathering ideas. 2). Drafting. It is free writing based on the big line. In free writing, writes whatever that comes up the mind. It is for gathering many sentences. $3)$. Reviewing. Is checking the error on the writing. It is about checking the grammar error, misspelling, and punctuation. 4). Revising. Is to fix all the errors in the writing. 5). Rewriting. Is to write the text again after being fixed before.

The other problem follows the students to make a writing. In the beginning, sometimes they are hard to start writing because the less of knowledge about the writing. They are difficult to organize the idea of writing. The idea that comes up sometimes did not refer to the writing, but the student still writes it. The lack of vocabulary and grammar knowledge makes the student difficult to build the sentences. The students are also difficult to organize the sentence into one good text.
The teaching technique also influences the students to make a writing. In teaching writing, the teacher can make various activities to make the student have a positive feeling to make a writing. So, the teacher should take a part in this problem. The teacher should help the students to feel positive with the English (Harmer, 2007:58). The teacher can use many varieties of learning methods. The teacher can make relevant learning or can do learning based on the experience. In conducting the writing class, there is a teaching method that can be used in the purpose to teach a writing. There are principles in teaching writing. Nation (2009:93) classify the principles for teaching writing are as follows:

a) Meaning-focused Input.

The process of writing focused on giving the students meaningful and successful writing. Meaningful writing is a writing task that contributes to the students' experience and knowledge. The student may express their mind about their experience.

b) Meaning-focused Output.

The process of writing focuses on the output of writing. The students pursue to do many kinds of writing tasks with different types of text or even different kinds of topics. This teaching has the purpose to make the student produce a lot of writing that will enrich them with knowledge and experiment about writing.

c) Language-focused Learning.

The process of writing that focuses on the language feature of a text. The students should understand the language structure and the process of writing itself. It used a critical issue include in the text.

d) Fluency Development.

The process of writing that focuses on the writing speed. They intend to be able to write with very simple material at a reasonable speed. 
This activity usually is done by doing repetition activity with an easy topic.

Many variations of the text also influence the student to make good writing. That text such as narrative text, descriptive text, recount text, procedure text, exposition text, and etc. each of the text has different characterizations and use. The student should master all of those characterizations that distract the student to put the correct form in a writing.

\section{Descriptive Text}

Descriptive text is a text that tells about an object based on our senses (Oshima \& Hogue, 2007:61). The text describes the object about how it look, smell, taste, sounds, and feels. The textonly tells about one object. The object can be a person, place, or things. The characteristic of the descriptive text itself is using adjectives $\&$ prepositions (Zemach \& Rumsek, 2006:25-7). With the structure consist of Title, Introduction that tells about general information and description that give the detail of the object.

A good descriptive text is a text that can give the reader full information about the object, then they can easily have an imagination about the object. In the case to make a good description, so it needs to focus on several things. First, descriptive text only focuses on one topic or object description. Second, descriptive text is written in good order. Third, follow the grammatical rule in writing descriptive text. Those characteristics can make descriptive text become a good one. To help the students to make a good descriptive can be done by using Spatial order technique

\section{Spatial Order}

\section{METHOD}

The purpose of the study is to find out the effectiveness of teaching writing using spatial order technique in writing
Spatial Order is the order of arrangement item by space (Oshima \& Hogue, 2007:62). It tells how an item located in order. In order means from one side to the other side. For example from the right side to the left side, or from the bottom to the top. Spatial order can be used in writing descriptive text. In the descriptive text, it needs to describe the object under a specific purpose. While writing using a spatial order, it describes the object as the order, which means it also describes the object specifically

When using spatial order in descriptive text, use the spatial order signals. Spatial order signal is the words or phrases that indicate the order (Oshima \& Hogue, 207:62). They are as follows: At the top of, In the center of, On the left, In front of, Inside, Next to, Between, Behind, In the back of, Across, etc.

The differences of this technique in writing descriptive text, that is in the way describing the object. With spatial order, the description based on the order. While, the other descriptive text, may describe an object randomly. There is no specific rule to make a descriptive text.

Based on the explanation above, the research is conducted to investigate the use of spatial order in descriptive text. Spatial seems to suit to be applied in descriptive text. It may help the students to decrease the problems that students have. The spatial order, help the students to organize and understand the idea well. Since the spatial order helps the writer and the reader to get the idea of the description. Furthermore, this research is conducted with this title with the purpose to know the effectiveness of the spatial order in writing a descriptive text and to know-how is the student's response towards it.

descriptive text and measure what are the students respond toward this technique of writing 
Based on those specifications, experimental research is held. The experimental research is conducted to find out the effectiveness of this technique and also qualitative research to find out the student's response toward this technique. Sugiyono(2015: 72) defines that experimental research is the research methodology with the purpose is to find out the effect of one activity that applied to controlled subject research. It means that there is a treatment that will be done to find out the effect of those treatments on the variables.

On the other hand, the type of preexperimental that used in this research is the One-group Pretest-posttest design. In this type of research, is used pre-test and post-test with the function to compare the score before and after the treatment (Sugiyono, 2015:74). There are two variables in this research. The independent variable in this research is the Spatial Order Technique for teaching descriptive text while the dependent variable is the students' writing skill of descriptive text.

The first instrument used in the research is the test sheets. The test sheet is a blank paper that contains the question about the test. These test sheets used to held a test. The test sheet for the pre-test is a descriptive text about the library. While the sheet for the post-test is descriptive about the schoolroom.

The second instrument used in this research is the questionnaire blank. The questionnaire blank used for the questionnaire technique that is to gather information about the response of the students using a closed questionnaire. The questionnaire is used a Likert scale. Likert scale is suitable to measure the opinion and perception of somebody toward social phenomena (Sugiyono, 2015:93). The social phenomenon in the research is about the research that gives the material about the spatial order technique. With a total of options is five. The bigger item score indicates that they are satisfied with the treatment. On the other hand, the lower the item score, the more dissatisfied the students with the treatment. This instrument is conducted at the end of the research.

Sukmadinata (2016:228) said that the validity of the instrument shows that the data of the research truly describe the variables of the study. Sukmadinata (2016:229) classify the things that make an instrument valid: 1)Content validity. This deals with the content of the instrument. The content should only find the data of the variables. 2)Construct validity. This deals with the structure of the instrument. The structure should give data about the treatment of the study. 3)Criterion validity. This deals with the criteria of the instrument that already used before to find the same data.

Data is the representative number scale of a variable (Latief, 2010:125). In this research, the data is taken from pretest and post-test. The analysis of the data itself is based on the result score of both pre-test and post-test. This data used to answer the problem of the research. It is to find the effectiveness of the variables. The researcher using a $\mathrm{T}$-test analysis for Dependent Variables to find out the significance of mean differences of pre-test and posttest. With the formula used are as follows:

$$
\begin{aligned}
t & =\frac{\text { Mean } D}{\sqrt{\left(\Sigma D^{2}\right)-\frac{(\mathrm{ED})^{2}}{N(N-1)}}} \\
\mathrm{t} & =\text { Significance of }
\end{aligned}
$$

data

Mean $\mathrm{D}=$ The mean

score of Differences (D)

On the other hand, data from the questionnaire is used to answer the problem of the study that is to find the student's response after using this technique. The data will be changed into a percentage, then be collected into a distribution table. The formula used as follows (Arikunto:2010): 
p-ISSN: 2085-1383; e-ISSN: 2621-4156

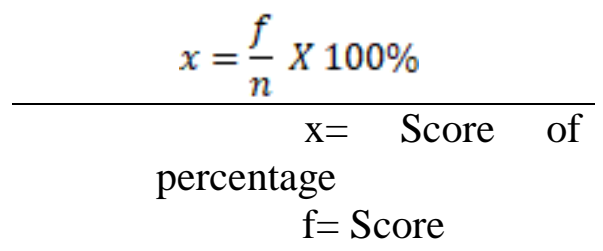

\section{The effectiveness of the Technique}

The effectiveness of the technique will answer the first research problem of this research. It is " How is the effectiveness of spatial order technique in writing the descriptive text for tenth-grade students in MA Sains Roudlotul Qur'an in the academic year 2019-2020"

\author{
$\mathrm{n}=\quad$ Maximum \\ Score
}

\section{DISCUSSION}

To know the effectiveness of the technique above is based on the data analysis of pre-test and post-test given to the students. The result of test score analysis will be checked in hypothesis testing. The Result of Pre-Test are as follows:

Figure 1. Graphic of Frequency Distribution in Pre-Test

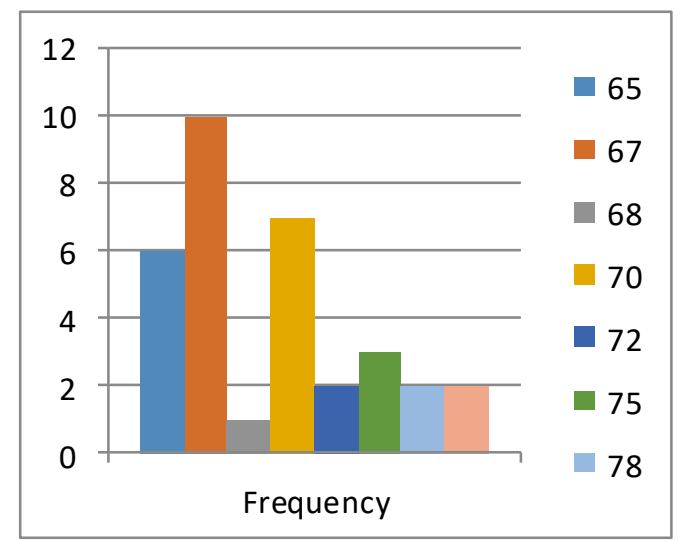

The mean score is just 69,79 . While the maximum score is 80 . On the other hand, the lowest score is just 65 . The passing grade that used in this school is 75 for English subject. This means, there are only seven out of thirty-three students that passed the test. It just $21,12 \%$.

Some of the students still do not get the idea of descriptive text. Descriptive text is a text that describes one particular object in detail. Unfortunately, there are still some students that insert a story about their experience in the tourism object in the test. Then, several students also describe two tourism object in one descriptive text. Some students, still have lack of idea of descriptive text.
They also used the wrong grammatical rule. In making a good descriptive text, the grammatical used are simple present tense and noun phrases. Most of the students are used simple past tense that totally out of topic. Most of them, also not use a noun phrase in their text. The other problem that the student has, that they still do not understand the structure of the text and also the paragraph.

In conclusion, based on the score above, that shows only $21,12 \%$ of students that have passed the test, while the other is failed to reach the passing grade. It becomes a very important point to conduct the treatment. The result of post-test are: 
Figure 2. Graphic of Frequency Distribution in Post-Test

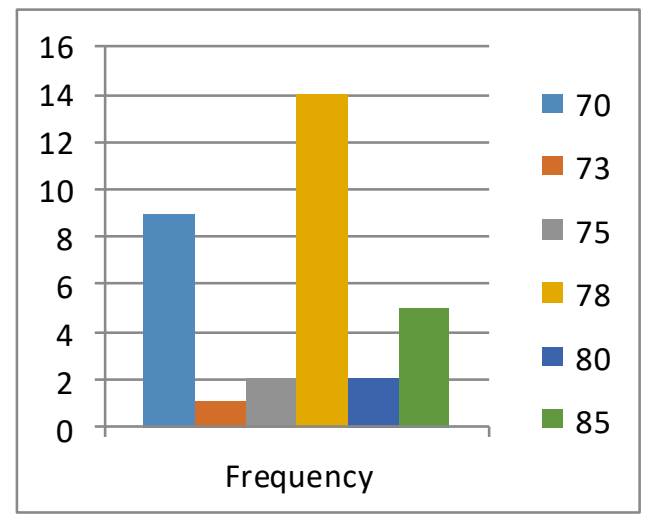

The mean score of the post-test is 75,58. It is higher than the pre-test. with the minimal score is 70 , which is higher than before. On the other hand, the maximum score is also increasing at number 85 . There are $69,69 \%$ of students that have passed the passing grade. It is also increased than the pre-test percentage.

Most of the students already understand the descriptive text. They get the idea of descriptive text. They just focus to describe the object, not telling a story. Unfortunately, few students still describe and telling a story about the object. All of the students use correct grammatical rules. All of them only use simple present tense, in making a sentence. Furthermore, they also used a noun phrase to describe the object specifically. Even though most of them still have lack diction in choosing the vocabulary, but the point is they have to use the correct grammatical rule.

Most of them also used the correct structure paragraph and text. The structure of the text is clear. They describe the object in the correct order. Even though some of them still have problems to make a good paragraph, but it can be fixed by the good order of the text.

In post-test, show the increasing score than the pre-test. The mean score, minimum, and maximum score are increasing. The knowledge about the text is also increasing. It indicates, the treatment brings something good to the student.

Data from pre-test and post-test is analyzed to get the result of the research. The result of the t-test from the data of the pre-test and posttest has found at the number $(t=6,65)$. The number of $t$-test with a number degree of freedom ( $D f=32$ ) based on the t-table, has found that at significant at the 0,05 the number of t-tests is $(\mathrm{t}=2,03)$, in the other hand the significant at 0,1 is $(t=1,69)$. It showed that t-test $(6,65)$ is higher than t-table ( $2,03)$ and $(1,69)$. As a result, as the t-test is higher than $\mathrm{t}$-table means that the $\mathrm{Ha}$ is accepted, while Ho is rejected. It means that it is effective in using spatial order te1chnique in writing the descriptive text for tenth-grade students of MA Sains Roudlotul Qur'an in the academic year 2019-2020.

\section{The Student Responses}

The instrument used to get the data of students' responses is using a questionnaire. The questionnaire is asking about the students to respond to some variables to measure. Those are English writing, Spatial Order technique, Study Interest, and Teaching Technique.

This is a closed questionnaire type. Given to the students after they get the treatment of the research. The give the score using a rating scale with number one 
Table 1. Table of Questionnaire Data

\begin{tabular}{lllcll}
\hline $\mathbf{R})$ & $\mathbf{( \% )}$ & Note & $\mathbf{( R )}$ & $\mathbf{( \% )}$ & Note \\
& & & & & \\
$\mathbf{A}$ & 49,33 & Less & $\mathbf{R}$ & 66,67 & Enough \\
$\mathbf{B}$ & 54,67 & Less & $\mathbf{S}$ & 73,33 & Enough \\
$\mathbf{C}$ & 49,33 & Less & $\mathbf{T}$ & 77,33 & Good \\
$\mathbf{D}$ & 69,33 & Enough & $\mathbf{U}$ & 60,00 & Enough \\
$\mathbf{E}$ & 68,00 & Enough & $\mathbf{V}$ & 69,33 & Enough \\
$\mathbf{F}$ & 61,33 & Enough & $\mathbf{W}$ & 66,67 & Enough \\
$\mathbf{G}$ & 62,67 & Enough & $\mathbf{X}$ & 64,00 & Enough \\
$\mathbf{H}$ & 61,33 & Enough & $\mathbf{Y}$ & 65,33 & Enough \\
$\mathbf{I}$ & 65,33 & Enough & $\mathbf{Z}$ & 60,00 & Enough \\
$\mathbf{J}$ & 66,67 & Enough & $\mathbf{A A}$ & 56,00 & Enough \\
$\mathbf{K}$ & 89,33 & Enough & $\mathbf{A B}$ & 62,67 & Enough \\
$\mathbf{L}$ & 68,00 & Enough & $\mathbf{A C}$ & 60,00 & Enough \\
$\mathbf{M}$ & 74,67 & Enough & $\mathbf{A D}$ & 60,00 & Enough \\
$\mathbf{N}$ & 62,67 & Enough & $\mathbf{A E}$ & 40,00 & Less \\
$\mathbf{O}$ & 74,67 & Enough & $\mathbf{A F}$ & 40,00 & Less \\
$\mathbf{P}$ & 58,67 & Enough & $\mathbf{A G}$ & 40,00 & Less \\
$\mathbf{Q}$ & 68,00 & Enough & & & \\
\hline
\end{tabular}

The analysis of the score percentage of the questionnaire shows the result as follows. One student gives a good score, twenty-six students are enough, and six students said, less. It Indicates, that there are twenty-seven students are given positive feedback. While the other six students show their response is less toward the treatment

Question number twelve, thirteen, and fourteen reach the higher item score in the questionnaire. The item tells about they like using spatial order techniques, they are motivated in using spatial order techniques and they like that they receive the technique. It means that the students are like with this technique. It can happen because be happened because they do not receive any technique in writing descriptive text. After they learn this technique, they like it and also motivated in using this technique for writing descriptive text. The students also glad to receive this new technique, because it gives them new knowledge.

In the other hand, question number two, three, and nine is placed on the last table. The item tells about the student's interest in writing descriptive text, asking students problems in making a paragraph, and descriptive text. It means the students dislike making descriptive text. it can happen because they do not understand well about the descriptive text. They do not get the idea about the paragraph in the descriptive text. By means, it makes them dislike making descriptive text.

The conclusion is, this technique can increase the student's ability in writing a descriptive text. It makes it easier to organize the paragraph, what to describe first, and how to describe it. Some probabilities to support this technique can give positive feedback, those are that this treatment gives the students new knowledge and deeper information about writing a descriptive text. Finally, from the explanation about, the conclusion is that the spatial order is effective to apply in writing a descriptive text. Also, most of the students give positive feedback towards this technique.

There is some probability of why this technique is effective for the students. This treatment gives the students new 
knowledge about the descriptive text. So, the students have deeper knowledge about the descriptive text and make it easy to write a descriptive text. Then, in using this technique, help the students to separate the paragraph easily. They are easy to choose the main idea of each paragraph because this technique rule the main idea is based on the order. It makes it easy to make descriptive text. Last, this technique is new to them. By the coming of this technique can help them to make the descriptive text easier.

On the other hand, the previous study that already conducted by Mildred Mason. Spatial order is used to help the students to comprehend the reading text. By means, this technique is also suitable for helping the students to make a descriptive text.

\section{CONCLUSION}

Based on the data above, can assumed that they were nervous while presenting or they still could not do how to make step of their own models. It

\section{REFERENCES}

Agustien, H.I.R. 2004. Literacy-based Approach: A Key to the Implementation of the 2004 English Curriculum. Paper presented at the $52^{\text {nd }}$ TEFLIN International Conference, Palembang, 7-9 December 2004.

Baker, J., \& Westrup, H. (2003). Essential Speaking Skills: A Handbook for English Language Teachers. London: Continuum.

Brophy, J. E. 1998. Motivating Students to Learn. McGraw-Hill, Boston, MA.

Chastain, K. (1998). Developing second language skills (2nd Ed.). Chicago: Harcourt Brace Publishers. supported by their response that $5 \%$ said the steps in making origami is very easy, $70 \%$ said easy, $26 \%$ said that it was difficult. It meant that most of them could make the steps easily. It may be caused by they often find the difficult words in using "origami'. It could be seen that $7 \%$ said very often, $30 \%$ said often and $58 \%$ said that they rarely find the difficult words.

Most of the students still had difficulty to make or present the sequence or step in making model orally. If they wanted to tell the steps they would write the instruction first. They motivated in learning English using "origami" as media especially procedure text. It is supported by the data that $37 \%$ said really motivate, and $63 \%$ only motivate but no one said not motivated.

But most of activities could be said that "origami" was successfully conducted based on the active participation on the students and their good responses. So, the writer can say that using "Origami" is a good way in learning procedure text orally.

Cohen, B.P. \& Cohen, E.G. (1991). From groupwork among children to $\mathrm{R} \& \mathrm{D}$ teams: interdepence, interaction and productivity, In Lawler, E.J.,

Creswell, J. (2003). Research design: Qualitative, quantitative and mixed methods approaches ( $2^{\text {nd }}$ ed.). Thousand Oaks, CA: SAGE Publications.

Depdiknas.2006. Standar Kompetensi Mata Pelajaran Bahasa Inggris Sekolah Menengah Pertama dan Madrasah Tsanawiyah. Jakarta: Depdiknas.

Foreman-Takano, Deborah. (1998). "Origami and Communication Strategies". Doshisha Studies in Language and Culture 1-2, 1998, pp. $315-334$. 
Panitz, T. (1996). A Definition of Collaborative vs Cooperative Learning. Deliberations, London Metropolitan University; UK, Retrieved 5 Nov. 2011, from: http://www.londonmet.ac.uk/deliber ations/collaborative-learning/panitzpaper.cfm.

Richards, Jack C., Theodore S. Rodgers. 1986. Approaches and Methods in Language Teaching. A Description and Analysis. Cambridge University.

http://www.origami-noa.com/index_e.htm retrieved on February 13, 2017.

http://www.oriland.com/oriversity/benefits /articles.

asp?category $=$ articles $\&$ model $=01 \& n$ ame=Five\%20Questions\%20About $\% 20$ Origami\%20Benefits, downloaded on Februari $17^{\text {th }}, 2017$. 